Man and Nature

L'homme et la nature

\title{
An Outline of Eighteenth-Century Russian Music
}

\section{Gerald Seaman}

Volume 5, 1986

URI : https://id.erudit.org/iderudit/1011860ar

DOI : https://doi.org/10.7202/1011860ar

Aller au sommaire du numéro

Éditeur(s)

Canadian Society for Eighteenth-Century Studies / Société canadienne d'étude du dix-huitième siècle

ISSN

0824-3298 (imprimé)

1927-8810 (numérique)

Découvrir la revue

Citer cet article

Seaman, G. (1986). An Outline of Eighteenth-Century Russian Music. Man and Nature / L'homme et la nature, 5, 165-176. https://doi.org/10.7202/1011860ar

Copyright (c) Canadian Society for Eighteenth-Century Studies / Sociéte canadienne d'étude du dix-huitième siècle, 1986
Ce document est protégé par la loi sur le droit d'auteur. L'utilisation des services d’Érudit (y compris la reproduction) est assujettie à sa politique d'utilisation que vous pouvez consulter en ligne.

https://apropos.erudit.org/fr/usagers/politique-dutilisation/ 


\section{An Outline of Eighteenth-Century Russian Music}

Yesterday I went again to a Russian opera whose music is composed of ancient native airs ... The words are by Her Majesty. The setting is splendid. The scene takes place in Russia in ancient times. All the costumes are absolutely magnificent; they are made of Turkish fabrics of the period and cut on the lines of the times. It features a legation of Kalmouks, singing and dancing in the Tartar manner; Kamtschadales dressed in the style of the country and they too dance the dances of Northern Asia; and finally a Chinese legation leading to the prince, the son of the Tsar, the princess destined for him. The ballet which closes the opera is danced by Pique, Mme Rosy and several other good dancers. In it are represented all the different peoples forming the Empire, each in their own distinctive dress. I have never seen a spectacle more varied nor more magnificent; there were more than five hundred people on stage, but even though the little Grand Dukes and the four little Grand Duchesses were there with their governors and governesses, there were hardly fifty of us spectators, so exclusive is the Empress in granting admission to her Hermitage ... ${ }^{1}$

Their minds receive very little cultivation, for they can neither read nor write: all their learning consists in a few proverbs, which they transmit from father to son. The labourer sings behind his plow, the coachman on his box, and the carpenter on the roof of the hut where he is at work; their songs are generally upon love and their music is very monotonous... One village has sometimes more than one church, and churches are in general very numerous in Russia, because it

MAN AND NATURE / L'HOMME ET LA NATURE V/1986

$0824-3298 / 86 / 0500-0165 \$ 01.25^{/ \mathbb{C}}$ C.S.E.C.S./S.C.E.D.S. 
is a work of great merit to found one. The ringing of bells is here almost continual, as it is thought to be part of religious service... ${ }^{2}$

These two accounts taken from the Letters of Count Valentin Esterházy, the French ambassador to the Russian Court, to his wife in 1791 and from the February number of the Scottish journal The Aberdeen Magazine, 1789, give a clear picture of the symbiosis of Russian musical life of the eighteenth century. On the one side was the great mass of the people, the peasants, largely illiterate, but drawing sustenance from the Church and at the same time preserving zealously their rich heritage of folk music. And on the other was the cultivated world of the nobility, whose love of Western culture manifest itself in the form of emulation of Western fashions, opera, chamber music and books. It was a symbiotic situation since both peasant and nobility depended on each other and there were a number of occasions when, as will be seen, the two worlds met. It was not unknown for wealthy aristocrats to marry one of their serfs, as was the case with Count Sheremetev, while a number of children sired by the nobility were given the advantages of a good education, even sometimes being sent to study abroad, as in the case of Mikhail Matinsky. It should not be thought that musical activity in Russia was concentrated in the end of the eighteenth century alone; indeed, in order to place the situation in perspective it is necessary to go back to 1700 and the period of Peter the Great.

As is generally known, Peter the Great was a towering personality, both literally and figuratively. Of enormous height and girth, his keen intellect was combined with the gift of imagination. As a realist he was fully aware of Russia's backwardness in comparison with Western Europe, which he not only visited in disguise but even worked in England as a ship-wright at Deptford dockyard - an event commemorated in Lortzing's opera Zar und Zimmerman, oder Die Zwei Peter, which in turn was based on a French play by Melesville, Merle and de Boirie. Peter lost no opportunity to gain knowledge of the Western world and there are several surviving accounts of his ambassadors' impressions, describing many facets of European social and cultural life, including opera, organ music, the custom of shouting 'Vivat!', musical entertainments and assemblies, and trumpet fanfares at meals. The value of these reports was immense, for nearly everything described in them was transplanted to the Russian soil and there forcibly implemented. The shaving of beards, the wearing of clothes in the German fashion, the organization of social gatherings and assemblies, which in turn gave to women a new place in Society - all these and other measures were ruthlessly put into operation - the penalty for disobedience being fin- 
ing, flogging or exile. Peter himself was not a great lover of music, though he liked to play the drum and was quite fond of sacred chant. Indeed, some surviving scores, beautifully and luxuriously bound, still bear the inscription: 'The Sovereign Pëtr Alekseevich deigned to sing from this music.' Peter also liked to use choral music as a means of enhancing the celebration of his victories and this led to the development of a simple musical choral composition known as a triumphal 'kant,' the form of which, it seems, was borrowed from the Polish Court. By the end of Peter the Great's reign, after years of neglect, plays were again being given in the Preobrazhensky village, a public theatre had been -established, a Court orchestra had been founded, assemblies were held frequently along with 'Tafelmusik' and trumpet fanfares, while foreign musicians and musical instruments were to be found in the household of foreign ambassadors and dignitaries in the new Russian capital of St. Petersburg. The 43 years of Peter's reign were some of the most significant in Russian history.

The reigns of Catherine I (1725-27) and Peter II (1727-30) were too short to have any effect on the development of musical life. Mention might be made, however, of a brief reference to opera in No. 1 of the Sanktpeterburgskie vedomosti (St. Petersburg Gazette), where there is an account of a production in Rome of a new opera in the palace of Cardinal Ottoboni in December 1728. That opera was still a new phenomenon to many of the paper's readers is indicated by the fact that the Editor found it necessary to explain that "Opera" is a musical work resembling a comedy in which verses are sung and extraordinary machines presented.' It was during the reigns of the three following rulers, however, that Russian musical life began to develop more quickly and it is one of those extraordinary quirks of fate that this was accomplished not by male sovereigns but by the three Empresses - Anna, Elizabeth and Catherine the Great.

Empress Anna, the daughter of Peter the Great's brother, Ivan Alekseevich, was no stranger to Western Europe, since she had lived for many years at Mittau, whose modest ducal household had some of the trappings of the larger German princely courts. When she was elected to the Russian throne in 1731, she endeavoured to use her new financial resources to full effect and within a year, it is said, she had not only Court singers and an orchestra at her disposal, whose task was to provide music for the numerous balls, civic, social, and theatrical entertainments, but distinguished foreign performers began to visit the capital with increasing frequency. Anna herself, however, was a strange mixture, her support of artistic endeavours being combined with a crude and rather grotesque humour, descriptions of which echoed for decades 
through the contemporary European periodicals. One of the most interesting developments in her reign was the fact that it saw the introduction of opera, this occurring in 1731 when Moscow was visited by two foreign opera companies, one led by $\mathrm{T}$. Ristori, the other by Johann Kaiser, whose repertoire appears to have been composed mainly of intermezzi. It seems that the first opera to be performed in Russia was entitled Calandro, this taking the form of a 3-act opera buffa with music by G.A. Ristori and text by S.B. Pallavicini. It was given at the Imperial Palace, Moscow, on 30 November 1731. Of great significance, however, was the visit to Russia in 1735 of an Italian Opera Company headed by the composer Francesco Araja, whose opera seria La forza dell'amore e dell'odio (The Power of Love and Hate) was given on 29 January 1736 at the St. Petersburg Court. The opera was performed in Italian by Italian singers, but the libretto was printed in Russian in a translation by the poet Trediakovsky. Decorative ballets were inserted between the various acts. Araja himself remained in Russia till 1759 and details survive of some of his other compositions. For the most part, however, performance of an opera was a rare event, and was reserved for special State occasions. There is also evidence that Russia may well have made the acquaintance of German Singspiel in 1740, during the visit of Neuber's dramatic company. This same period also saw the arrival of a number of distinguished composers and performers from abroad, including the violinists Giovanni Verocai, Luigi Madonis and Domenico dall'Oglio, all of whom wrote instrumental music. A copy of Madonis's Douze diverses Symphonies for violin and bass, along with its elegant dedication to Anna, still survives. What is also interesting is that, according to Jakob von Stählin, Madonis composed several sonatas based on Ukrainian themes and it is possible that these early essays into the employment of folk material provided examples which subsequent composers living in Russia were to follow at a later date. There is evidence that gusli-players also performed at Court (the gusli being the equivalent of the Medieval psaltery or the Hungarian cymbalom), and Ukrainian bandura-players were also popular, the most celebrated being Timofei Belogradskii and his family, c. 1739. Affection for things Ukrainian continued into Elizabeth's time since her lover, Count Razumovsky (nicknamed the nocturnal Emperor, since he reigned at night!) was himself of Ukrainian origin and a good singer. Another event towards the end of Anna's reign was the construction of a large organ in the Lutheran St. Petri-Kirche in St. Petersburg, this being consecrated in December 1737. The organ was built by foreign masters, the first organist being Joachim Bernhard Wilde. A small music school was founded under J. Hübner in 1740, the purpose of which was to train young Ukrainian singers as Court musi- 
cians, another school being opened at Glukhov in the Ukraine in 1741. A choreographic school had already been founded in 1738 by J.-B. Landé. A printing press was established in the Academy of Sciences, whose tasks included not only the publication of books but also the printing of music. The first musical work to be published in Russia seems to have been a triumphal 'Kant' by Trediakovsky, written to mark the occasion of Anna's coronation in 1731.

The death of Anna was followed by the accession of Empress Elizabeth in 1742 , an event which was marked by a performance of an opera $\mathrm{La}$ Clemenza di Tito, with music by the German composer Johann Hasse. The 1750's saw several performances of Italian opera buffa and French opéra comique, a trend which was steadily to increase during the course of the century. Of special interest from the point of view of the history of Russian music was the appearance in 1755 of the first opera to a Russian text, this being Tsefal $i$ Pokris (Cephalus and Procris), with music by Araja and libretto by Sumarokov, the soloists being young Russian and Ukrainian singers and the chorus consisting of the Court singers. Musically, however, there was no national colouring and the work was essentially a conventional opera seria. Elizabeth's reign also saw the opening of several new theatres, namely the Russian theatre in St. Petersburg 1756 (Sumarokov being its director), and the Locatelli Theatre in Moscow in 1759. French plays were popular, while at dinners, suppers and masquerades, Italian music was an essential part of the proceedings.

It was during the reign of Catherine the Great, however, that Russian professional music truly came into being. The thirty-four years of Catherine's reign, beginning in 1762, saw immense changes in all walks of life, not the least those in the field of culture. A zealous adherent to the ideals of enlightenment (at least in her early years), Catherine carried on an extensive correspondence with leading European intellectuals, including Diderot, Voltaire and Grimm, while her Court, centered round the great Hermitage and occasionally resident at the palaces of Peterhof, Gatchina, Oranienbaum, Tsarskoe Selo and Pavlovsk, became a meeting point of celebrated foreign composers and virtuosi. Manfredini, Galuppi, Traetta, Sarti, Cimarosa and Paisiello were only some of the distinguished visitors, Paisiello's Barber of Seville, one of the most popular and successful opera buffa of the eighteenth century, receiving its world première at the St. Petersburg Court in 1782.

When Catherine first came to the throne she was extremely patriotic, the fundamental principle in her manifesto being the protection of the Russian faith and nationality.' It was largely due to her interest in Russian culture, no doubt inspired by the international concern for folk art 
as seen in the work of Herder, Macpherson and the cult of nature, that the first collections of Russian folk-songs started to appear in the 1770s, notably those of Trutovsky, Chulkov and Prác. Although collections of folk-songs had appeared earlier than these in other countries, especially England, Scotland and Wales, the Russian collections were interesting in that the songs were divided into special genres. It is significant, therefore, that the year 1772 saw the appearance of what appears to be the first real Russian opera, this being the comic opera Anyuta performed at Tsarskoe Selo on 26 August, with libretto by M. Popov. Unfortunately the name of the composer is unknown and the music has been lost. Examination of the libretto, however, indicates that specific numbers were sung to wellknown folk-tunes, the overall structure of the opera being that of the Singspiel type, with spoken dialogue alternating with musical items. Of the various subsequent Russian operas, of which about a hundred seem to have been written in the course of the last years of the eighteenth century and about a third of which have survived, several may be singled out for comment.

The first Russian opera to enjoy really prolonged success was entitled Mel'nik-koldun, obmanschchik $i$ svat (The Miller-magician, Deceiver and Match-maker), the libretto of which was by Aleksandr Ablesimov, a talented playwright, who also stipulated the use of a number of wellknown folk-tunes, which were sung to his words. First performed in Moscow on 20 January 1779, the subject of the opera, which is very simple, almost certainly owed something to Rousseau's famous opéra comique, Le devin du village, which, according to Robert-Aloys Mooser, was possibly given in Russian at the Theatre of the Moscow Orphanage in $1778 .^{3}$ The plot is concerned with a wily miller, who is supposed to have magic powers. A young man, Filimon, seeks his aid, and the Miller betroths him to Anyuta, at the same time deceiving both her parents in turn. He tells the gullible father that the young man is a peasant, and the even more gullible mother that he is a nobleman. He eventually satisfies both parties by disclosing that Filimon is actually an 'odnodvorets' (i.e., a freeholder) and is thus both a landowner and a peasant at the same time. The music was arranged in the first place by Sokolovsky, a violinist at the Moscow Russian Theatre, but was later revised by Fomin. Indeed it was under Fomin's name that a vocal score was published by Jurgenson in 1884. By far the best number in the opera, however, is the overture, which, though originally ascribed to Fomin, now appears to be the work of the Czech composer Vancura, for the operatic overture is almost identical with a 'Russian symphony on Ukrainian Songs' published under Vancura's name in the October No. (1790) of a Journal de musique, dedié aux dames. The overture itself utilises two folk-songs, which are very 
similar to ones found in the folk-song collections of Trutovsky and of Prác.

The opera Neschast'e ot karëty (The Misfortunes of having a Carriage), with words by Knyazhnin and music by the Russian composer Pashkevich, is perhaps more remarkable for its libretto than its music. Presented at the Hermitage Theatre on 7 November 1779, the story is concerned with an eccentric landowner, Firulin, and his wife, Firulina, who have an exaggerated admiration for everything French. Firulin's latest passion is a new French carriage, which he can only obtain by selling Lukyan, one of his serfs, into the army as a recruit. His bailiff, whose name Firulin has changed from Clementi to Clement, is entrusted with this task. Even though this was to be Lukyan's and Anyuta's wedding day, their pleas are in vain. When Lukyan resists the bailiff, he is put in chains. In Firulin's eyes, nothing Russian has anything to recommend it. The language is harsh-sounding, the people are barbarous, their very names offend the delicacy of his ear. When asked to show pity, he exclaims: 'Pity for Russians. You must be out of your mind. I left all my pity behind in France. I can hardly restrain my tears, remembering Paris!' Eventually, however, the situation is saved. Lukyan and Anyuta have somewhere picked up a few French words. On the advice of the Jester they fall on their hands and knees before their masters crying: 'Monseigneur, have pity on us!' 'Madame, intercede for us!"Mon coeur,' says Madame, 'he knows French and is in chains. This won't do!' and they are released. But Firulin still hasn't forgotten his carriage. Even if he is willing to let Lukyan and Anyuta get married, he can always sell a few others instead...

Catherine herself wrote a number of libretti of which special mention should be made of Fevey and The Early Reign of Oleg. Both these works were staged extremely elaborately and we are fortunate that first hand accounts of their performance have been preserved for posterity in the letters of Count Valentin Esterházy. In the opera Fevey (1796), the music of which was written by Pashkevich, two numbers are of particular interest - the song of Ledmer and the Chorus of Kalmyks. Ledmer's song is a curious anticipation of the type of 'changing-background' technique, which Glinka and his successors were to use with great effect in the following century, for the same tune is repeated incessantly against varied harmonisation and orchestration. The Kalmyk chorus is interesting in that it is an attempt at composition in an exotic vein, likewise a facet that was to be developed in the nineteenth century. One of the most gifted composers of the period was the Ukrainian, Dmitry Bortnianskii, who though better known for his sacred music, nevertheless wrote a number of operas. Like several Russian composers (Matinsky, 
Fomin, Berezovsky, Degtyarëv) Bortnianskii was sent to Italy to complete his musical training, having taken lessons from the distinguished Italian composer Baldassare Galuppi in St. Petersburg. In Venice Bortnianskii wrote three operas, being commissioned on his return to compose a further two - Le Faucon in 1786 and Le Fils Rival of 1787. Of these Le Faucon (The Falcon) was written to a French libretto by Lafermière and was first given at the Court of Prince Paul, Catherine's son. Based on a subject from Boccaccio's Decameron (Fifth Day, Tale IX), the music is impeccably written and recalls in its smooth elegant lines the sculptures of Canova, the classical structures of Cameron and Rastrelli and the elegant penmanship of Karamzin.

The name of Mikhail Matinsky has already been mentioned, for Matinsky was the illegitimate son of Count Yaguzhinsky. Born in 1750 in the village of Pokrovsk near Moscow, he studied at Moscow University and was sent to Italy at his father's expense. Between the years 1779-1802 he was, like Prác, a teacher at the Smolny Institute for Daughters of the Nobility. He seems to have died some time in the 1820's. Matinsky is certainly the author of the opera Sanktpeterburgsky gostiny dvor (The St. Petersburg Bazaar), which was come down to us only in its second version of 1792 under the title Kak zhivësh, tak $i$ proslivësh (As you live, so are Judged), but whether he was actually the composer of the music is currently disputed. Latest Soviet scholarship proposes the name of Pashkevich, but the surviving music is so much better than any of Pashkevich's other compositions that it is hard to accept this suggestion. The plot of the opera is concerned with the crooked dealings of the merchant Skvalygin. Skvalygin (whose name literally means 'miser,' 'skinflint') is about to marry his daughter Khavronya (literally 'sow' or 'pig') to a cold-blooded scrivener, Kryuchkodey ('caviller,' 'twister'). Wedding songs are sung. But after trying to cheat their creditors in various ways, they are thwarted; justice prevails and the final chorus ends with the words: 'Reign, holy truth, reign in our times!' Of the many good numbers in this opera, outstanding is the sextet in which the four merchants Razzhivin, Protorguev, Pereboev and Smekalov endeavour to attract two buyers, Shchepetkova and Krepyshkina. 'Here, ladies, what do you want?' cries one. 'This way, ladies!' cries another, and, according to the Russian musicologist, Nicholas Findeizen, these merchants' cries could be still heard in the Apraksin and Alexandrovsky markets up to the end of the nineteenth century.

Another gifted Russian composer was Evstigney Ipat'evich Fomin (1761-1800) who likewise completed his musical training in Italy, studying under the celebrated Padre Martini and being elected a member of the Bologna Academica filarmonica in 1785 . Of Fomin's various operas, par- 
ticularly vivid is his opera Yamshchiki nad podstave (The Post-drivers at the Post-station), written to a libretto by N.A. L'vov (who, it will be remembered, collaborated with Prác in the devising of his folk-song collection). The story is very slender and describes how the villian, Filka Prolaza (literally, 'Filka the sly one'), endeavours to have the hero, Timothy, called up as a recruit instead of himself. The plot misfires, however, and with the help of a passing officer, Filka is himself conscripted. Most effective in the opera are the lively Overture, which employs two folk-songs, and the opening chorus, likewise based on folk material. In listening to these numbers, one involuntarily recalls the extract from The Aberdeen Magazine'...the labourer sings behind his plow, the coachman on his box...' Fomin was also responsible for the 2-act melodrama Orfey i Evredika (Orpheus and Euridice), written in 1791-92 and based on a libretto by Knyazhnin. Apart from the unusual orchestral devices, the melodrama is also remarkable in that Fomin introduces a Russian horn band to strengthen the chorus of bass voices (symbolising the Gods), this being heard off-stage. The Russian horn band was a remarkable phenomenon of the second half of the eighteenth century. Consisting of a band of serf musicians, each of whom played only a single note, the horns varied in size from about 3 inches to over 8 feet in length, this giving a total range of some $41 / 2$ octaves with all the chromatic intervals. One of the most famous of these was that developed by Anton Maresch, a Bohemian, for Prince Naryshkin. According to one source, between 1753 and 1796 there were no less than nine of these bands in St. Petersburg as well as others in Moscow and the provinces. The music was written in a special type of notation and sometimes was of astonishing complexity. ${ }^{4}$ Fomin's employment of a Russian hornband in a dramatic work, therefore, is a good indication of its popularity at the time.

Before passing on to a brief discussion of some aspects of secular music, a few words must be said about sacred music, in which a notable part was played by the composers Bortnianskii, Berezovskii and Degtyarëv. Just as Russian sculpture and architecture was strongly influenced by Italian culture, so was Russian sacred music influenced by Galuppi (who was for several years Director of the Imperial Chapel and teacher of Bortnianskii), and Giuseppe Sarti, the teacher of Degtyarëv. Bortnianskii is remembered particularly for his sacred concertos, in which excellent contrapuntal technique is combined with smooth part-writing, sensitivity towards the disposition of the vocal parts as well as an element of devotion. To Sarti belong a number of sacred and secular oratorios, such works often being conceived on a lavish scale, demanding large forces. His Te Deum, for instance, written to mark the victory of Prince 
Potëmkin at Ochakov in 1789 , employed not only solo and choral elements but bells and cannons as well. Large choral and orchestral forces, too, are stipulated in his 'Oratorio Russe.' Of importance are the various works for unaccompanied violin, for violin and viola, or for two solo violins, by the gifted Russian violinist Ivan Evstaf'evich Khandoshkin (1747-1804), a number of whose pieces take the form of variations on Russian folk-songs.

No survey of Russian music of the eighteenth century would be complete without reference to the part played by the musical amateur, for just as in other parts of Europe and the New World there was an everincreasing demand for uncomplicated new music, the same situation prevailed in Russia. Of great popularity were the works of the Polish composer Kozlowski, whose polonaises were heard constantly throughout fashionable society. The Polonaises are found both in orchestral form and arranged for keyboard, where they enjoyed great popularity. Numerous accounts give details of the prevalence of the harp and guitar in cultured circles, such instruments being used not only as accompaniment to the sentimental songs and 'romances' of the period, but sometimes being included in chamber ensembles. And just as the eighteenth century saw an ever increasing number of periodical publications in Western Europe, so, too, in Russia did the first music journals start to appear. Such were the Giornale musicale del Teatro italiano di St. Pietroburgo of 1795, edited and produced by Bernhard Theodor Breitkopf, the son of the Leipzig music publisher, and the Magazin muzkal'nykh uveseleniy (Journal of Musical Amusements) produced in the same year of 1795 by Selivanovsky, a Moscow publisher and bookseller. Quite outstanding, though, are the two so-called Karmannye knigi or 'Pocket-books' for Lovers of Music, produced in 1795 and 1796 by Gerstenberg, an enterprising German born in Leipzig, who came to St. Petersburg about 1790. The content of these pocket-books is quite diverse, containing calendars, portraits, descriptions of composers and musical forms, musical games, anecdotes and other materials, which are similar to those found in comparable publications in Western Europe. Where the pocket-books differ, however, is in their printed musical content, the 1795 volume for instance, containing six Russian songs by the composer Dubyansky and 'Two Russian Songs with Variations' by Palschau. Such songs, with their sentimental texts and plaintive melodies, were extremely popular at the time, as is seen from the fact that they crop up constantly in anonymous vocal collections of the period. ${ }^{5}$

Before concluding one may well reflect on the manner in which Russian music developed in the course of a hundred years. When Peter the 
Great came to the throne, musical life was manifest almost solely by sacred music and the richly developed heritage of folk music. There was no opera, no symphonic music, no chamber music, no public concerts, and at a time when the Collegium musicum was a vital force in Western Europe, when the tragédies lyriques of Lully were being staged with unbelievable magnificence at the Court of le Roi soleil, and Italian opera seria was sweeping through the great theatres of Italy and England, Russia was still a feudal state. But, as has been described, in the hands of Peter the Great and the Empresses Anna, Elizabeth and Catherine, by availing themselves of Western expertise, in a remarkably short time Russia endeavoured to make up for a Renaissance and Baroque period which had never existed and to leap from the Middle Ages into the midst of the Classical period. True, there was a great dichotomy between nobility and peasant, but, on occasions, both derived pleasure from a common source. The humble peasant melody was translated into the noble salon and the melancholy folk-song became the subject of a contrapuntal theme and variations.

\section{GERALD SEAMAN}

University of Auckland

New Zealand

\section{Notes}

1 Lettres du Comte Valentin Esterházy à sa femme 1784-1792 (Paris, 1907) Letter dated Petersbourg 11 Octobre -30 Septembre 1791, 318-19

2 'Some particulars respecting the Manners and Customs of the Russian Peasants,' The Aberdeen Magazine, Thursday 12 February 1789, 65-6

3 See R.-A. Mooser, Opéras, intermezzo, ballets, cantates, oratorios, joués en Russie durant le XVIII siècle. (Basle: Editions Barenreiter 1964) 42.

4 A unique account of a Russian horn band is to be found in the June No. 1824 of the English journal The Harmonicon, where, in an article entitled: 'From the F sharp of the Russian Imperial Horn Music,' we read the following:

Sir,

In a country where philosophy and political science are applied to the purpose of reducing man to his most simple expression, all institutions have a particular character, which may appear strange to the civilized inhabitants of those countries, where some kind of liberty exists, and where the dignity of human nature is not abased to a condition that is merely mechanical and vegetative.

Russia, as you are well aware, is that part of Europe into which the light of science has the least penetrated. 
You cannot be ignorant that music (I mean musical execution,) is a very different thing at Petersburg, from what it is at Vienna, Berlin, Milan, Paris, London, in a word, in any other part of the world where melody has made some advances. A concert of harmony at Petersburg is composed of about four-and-twenty musicians. The functions of each of these performers, are limited to the giving of a note, of one single note. The most rigid and scrupulous attention is the only instinctive quality exacted of these bellows in human form; hence they show no disposition for any other talent, because they have no idea of extending their range of thought beyond this limited sphere. They are in every respect automata, possessed of no determinate faculty.

Can you figure to yourself a man reduced to the condition of an organ pipe? Will you believe, sir, that the person who now addresses you, has, during thirty years of his life, been the F sharp of the music of the Emperor of all the Russias? I was called, at least I am willing so to believe, to more brilliant destinies; but a cruel event has changed my fate. My fortune having been destroyed in one single day, I was reduced to the necessity of soliciting the favour of the court; I hoped for an employment worthy of a thinking being, and they have conferred upon me that of a piece of mechanism. I became mono-musical at the rate of a hundred roubles per annum.

One day I took it into my head to play an entire air upon a flute, which had been sent me from France. As a return for my presumption, I received a dozen lashes of the knout, which were unsparingly applied, and my appointment stopped. After this I blew for six months for the King of Prussia, but wearied out at length by the rigorous treatment I was doomed to endure, I deserted from a body where no encouragement is held out to emulation, and from a country, where intelligent beings are converted into wind instruments, incapable of any further degree of advancement. My comrades, G, B flat, and A, have followed my example. We are lately arrived in London, and wish to give some concerts. We purpose playing an air in four notes, and solemnly assure you that we will not cheat the public by being pleasing; we will scrupulously adhere to the prevailing fashion, and be only surprising.

We have, and that may prove a disadvantage, no condemned, fugitive felon in our band; nevertheless we hope that the novelty of our performance may excite some interest, and that it may inspire pity for the slaves, whom ignorance has reduced to the barbarous condition, in which was lately

Your humble servant,

Kouloff,

Former F sharp to H.I.M. the Emperor of all the Russias May 3d, 1824

5 For a fuller discussion of these periodicals see: G.R. Seaman. 'An EighteenthCentury Russian Pocket-Book.' The Slavonic and East European Review 60 (1982) 262-72 